\title{
TRAINING AND RETRAINING AS A TOOL FOR PROMOTING WORKERS' PRODUCTIVITY IN NIGERIA
}

\author{
Dr. MABEL OYITSO AND Dr. (Mrs.) OLOMUKORO, C. O.
}

\begin{abstract}
Human resources are the key element in any organization as they plan, coordinate, organize and harness all other resources towards the achievement of organizational goals. For any organization to increase its productivity level depends on the level of competence of its workforce. Hence, the need for training and retraining of workers to develop their abilities in order to function effectively and efficiently in the organization. Training is an indispensable tool for human and national development, hence a worthwhile investment for greater productivity in the organization. Training can be viewed as the acquisition of skills, knowledge and abilities to enable one function effectively in the performance of one's job. The major types of training for workers are in-service training made up of on - the - job and off - the - job training. Training makes workers to be confident, enriches employee's knowledge and increased performance skill, creates greater efficiency and effectiveness, increases productivity and leads to higher profitability. The major problems affecting the training of workers are inadequate finance and lack of constant training. Therefore, periodic training should be organized for workers to keep them abreast of technological changes in their work and adequate financial allocation should be devoted to training of workers in the organization.
\end{abstract}

Key Words: Training, re-training, Nigeria workers and productivity.

\section{Introduction}

Human beings are the pivot of work in the productive venture. This explains why organization and nations take good steps to ensure the effectiveness of individual. Human beings provide ideas, innovations, invention and thereby wealth for the benefit of both employers and employees. This cannot be achieved if workers are not properly trained. Hence, training has always been recognized as an important factor that contributes to improved performance of an employee right from the days of Fredrick Taylor of Scientific Management (Maduabum, 1992:183).

Training can be viewed as the acquisition of skills, knowledge and abilities to enable one function effectively in the performance of one's job. Training of workers is very important to the development and growth of any country most especially the organization. Training is meant for increasing the usefulness of the worker at the work place. The need for training workers in any organization is to develop and use their abilities for the achievement of organizational goals and the fulfillment of individual job satisfaction. The Federal government recognized the importance of training and re-training of workers to the development of the nation, hence, the Federal Republic of Nigeria (2004) in the National Policy on Education as the demonstration of the government's commitment, Section 7, Sub Section 4 of the Policy states that: 
For all classes, different kinds of in-service training, courses and seminars related to their particular occupations will be arranged on a continuing basis so that all workers may attain proficiency in their work.

As a result, the Nigerian government has made certain effort in establishing training centres like the industrial training fund and administrative staff college of Nigeria to train skilled manpower to man the various sectors of the economy. The training is aimed at increasing workers efficiency and productivity level of organization and accelerates economic development in general. The paper therefore examined the meaning of a worker, training / retraining and types of training available to workers. Also discussed included objectives of training and effects of training on workers' task performance in the organization.

A worker is any individual who is engaged in a particular service in anticipation of agreed wages to be paid in return for the services he renders to his employer (Imhabekhai \& Oyitso, 2000). This in essence means that a worker is anybody in paid work. The workplace injury management and workers Compensation Act of 1998 (the 1998 Act) section 4 defines a worker as follows:

Worker means a person who has entered into or works under a contract of service or training contract with an employer (whether by way of manual labour or clerical or otherwise and whether the contract is expressed or implied and whether the contract is oral or in writing.

Wikipedia (2011) defines a worker as one who works at a particular occupation or activity. For example, an office worker is one who does manual or industrial labour. A worker can also be a person who is employed to do physical or mental work for wages in order to earn a living (http://www.yourdictionary.com/worker). This means that the individual is paid for services rendered or labour exerted in doing his job. Also, a worker can either be employed in an industry or be self employed. In the context of this paper, a worker is any person employed by the government or private organization to produce goods or render services to humanity and at the end, the person is rewarded through the payment of salaries or wages.

The term training has been defined in various ways by different authors. Training refers to improving competencies needed today or very soon (Jackson \& Schuler, 2003). Training is the act of increasing the knowledge and skills of an employee for performing the job assigned to him. It is a short term process. The term training refers to the acquisition of knowledge, skills and competencies as a result of vocational or practical skills and knowledge that relates to specific useful competencies (Wikipedia, 2011).

Training is any attempt to improve current or future employee's ability to perform through learning (http://@ dictionary.com/worker/3045). The purpose of training is to achieve a change in behaviour of those trained. Training is also a learning process that involves the 
acquisition of knowledge, sharpening of skills, concepts, rules or changing of attitudes and behaviour to enhance the performance of employees. It is activity leading to skilled behaviour (http:/training and development; naukrihub.com).

According to Nwachukwu (1998), training is an organizational effort aimed at helping an employee to acquire basic skills required for the sufficient execution of the functions for which he was hired. Training generates expertise or skill needed to perform a particular job or series of jobs. Training involves a wide range of professional activities for workers which contribute to their enhancement of work. It can be visualized as the acquisition of techniques, skills, knowledge and experiences which enable the individual to make effective contribution to the combined efforts of a team in a productive process.

On the other hand, re-training of workers involves the renewal or updating of worker's skills, knowledge, attitude, work habits and competencies to enable them perform their assigned responsibilities creditably (Imhabekhai, 2000:120). He went further to say that re-training is a function of observed training needs and the amount of changes which have taken place in the techniques of production. Stressing the importance of re-training to employees, Imhabekhai (2000: 120) maintains that:

It is expensive to expect a man to pick up the thread as he goes along. Thus, at different levels in various ways, training for management succession is being fulfilled and grudgingly accepted to be vital for the well-being of an enterprise. Training is a means to an end in itself, the end being the prosperity of the enterprise (2000: 120).

Re-training of workers is very vital to the productivity of any organization considering the technological changes taking place in the world of work. This means workers must be trained to acquire the necessary skills and knowledge to be able to meet with these changes and perform their assigned roles in the organization towards the achievement of organizational goals.

\section{Types of Training for Nigeria Workers}

The major forms of training for Nigeria workers include the following:

In-service training made up of:

On-the-job and (b) Off-the-job training.

Formal training 


\section{In-service Training Programmes}

These include training programmes specifically organized for workers who are already in employment. In-service training essentially takes two forms namely: on-the-job training and off-the-job training.

\section{On-the-job training}

Takes place at the work place and possibly while at work. According to Egungwu (1992), onthe-job training takes place at work location. Responsible for its implementation is primarily that of the immediate superiors. On-the-job training is given to new employees by their organization irrespective of their previous training and experience. Orientation or induction training is given to these new workers to familiarize them with their new work environment and the operations of the establishment. The aim of every induction course is the enhancement of the psychological integration of new employees to their work environment. Induction or orientation programmes are desirable and inevitable if the employees must render their services creditably. That is why Pigors and Myers (1984: 44) submitted that:

No organization can choose whether or not to train new employees. All new employees regardless of their previous training, education and experience need to be introduced to their new work environment and to be shown how to perform specific tasks. Specific training occasions arise when employees are transferred or promoted or when jobs changed and new skills must be learnt, perhaps because of changes in technology and automation.

\section{Off-the-job Training}

This takes place outside the work environment and are provided by established training institutions. They are necessary when some employees require the acquisition of the type of knowledge, skills and attitudes which are best provided through series of courses carried out of job environment (Egungwu, 1992). Nigeria workers are provided with opportunities for continuous learning and acquisition of knowledge and skills needed for effective performance of their jobs and increase in productivity. On-the-job training is provided for workers by established institutions like Administrative Staff College of Nigeria (ASCON), Nigeria Institute of Management (NIM), Centre for Management Development (CMD), Industrial Training Fund (ITF), and host of others. Off-the-job training is also provided through regular attendance and participation in seminars, conferences and workshops. According to Imhabekhai, (2000:122); this mode of training connotes the gathering of likeminded persons for the purpose of education or getting educated about something or a phenomenon through the acquisition of knowledge, skills and attitudes. Conferences, seminars and workshop are very vital in training manpower in Nigeria. This is because they constitute fora for experts, researchers, practitioners, policy makers to come together to share 
new ideas in the areas and most recent innovations in administration and management of these various establishment.

\section{Formal Training}

This is the training received in formal institutions such that spans from primary to tertiary institutions. According to Ndiomu (1992), formal schools are the traditional places for acquiring knowledge and skills, for they provide the atmosphere for structured learning which makes assimilation process easier. This is so because of the concentration of teaching efforts, aid and feedback mechanism. He went further to say that training in formal schools has the following advantages:

1. The performance level of the study can be readily assessed through testing;

2. Ideas and concepts can be standardized;

3. It affords students from various background and experience a forum for interaction; and

4. Resources are put together in one place for maximum utilization.

This type of training provided to a worker depends on the training need of the worker and objectives of the organization. In other words, an organization provides training to its employees on the area he needs training and to achieve organizational objectives.

\section{Objectives of Training Workers}

The objectives of training according to Akinwale (2000:35) can be examined along the following dimensions namely:

- Organizational level;

- $\quad$ Individual level; and

- $\quad$ Employee level.

At the organizational level, training is very important in order to meet corporate goals. The need for training must be identified continually in order to achieve organizational goal. Opportunities for training therefore are used as a response to organizational expansion and change. In line with the above, Lane \& Robison, (1995) are of the opinion that training impacts positively and effectively for optimum performance to achieve corporate goals of the organization.

At the individual level, every organization recruits the best staff it is capable of recruiting within the limits of its environment. Training reduces the work of the manager in terms of close supervision. Training allows for job understanding and competence of the individual. Training at the employee level improves the drive, initiative and quality of work of employees. The employee therefore becomes capable of coping with challenges. Training provides the means of maintaining their own competition by improving knowledge, skills and abilities (Lane \& Robison, 1995). 
The objectives of manpower training and development according to Archive (2008) are to:

1. Help yield operational results that will bring about meaningful changes in the output of the organization;

2. Develop, sharpen and thus change the employees' attitude as well as increasing their knowledge and skills; and

3. Changes in techniques and automation and the consequent effect they have on the existing skills and jobs have necessitated the need for the continuous training of the employees.

The primary objectives of workers' training are to equip workers with the necessary knowledge and skills at all levels for the successful attainment of the desired goal of the organization. To achieve this objective, the organization designs training programme for its staff. Effective training to an employee will assist in providing the knowledge and appreciation of techniques necessary to enable the trainee to do his job. According to Oladubu (1991) the objectives of training a worker are:

1. To be better equipped to adjust to the changes in the nature of his work.

2. To widen the trainee's understanding of the society in which he lives and develop him as a confident person; and

3. To afford the staff the opportunity of changing their schedules of duties and to be able to perform equally well on them.

Equally, Omole (1999) noted that the purpose of industrial training includes the improvement of the present or future competence of the individual with a view to improving the competence of the team, group or organization, thereby serving a dual purpose. He went further to say that the rapid changes taking place in the field of technology all over the world demand that workers must be trained to catch up with the changes. Hence, Smith (1977: 34) opines that:

The rate of technological changes has accelerated so that worker can start at the age of sixteen and remain in the same type of job until he retires. Indeed, it could be argued that we have moved into the two or three skill society, where it is the accepted pattern to have to change their type of employment.

The overall aim of training and retraining workers is to improve the efficiency of the work force and to increase the productivity of the organization.

\section{Effects of Training on Nigeria Workers}

The various training programmes undertaken by workers have great impact on the performance of their jobs and the overall productivity of the organization. That is why Ubeku (1975: 143) noted that: 
Investment on training and development of staff are wise investment. There are many organizations or establishments in this country due to either ignorance or selfish motives regard training as an expensive venture or waste and so avoid them like plague. What such organizations are interested in are the returns.

Systematic training has contributed significantly to the achievement of organizational goals which provided good judgment about diminishing returns. Staff training exposes workers to take additional duties and assume positions of importance in establishment hierarchy. Technology is becoming more and more complex and even computerization is applied, training and re-training have helped workers to acquire different types of skills and competences required to fully achieve organizational goals. According to Ubeku (1975) the benefits of training and development of manpower to both the organization and individual workers are many. To the organization the benefits include:

- $\quad$ Better production;

- $\quad$ Reduce waste accidents and cost of operation;

- $\quad$ A stable workforce; and

- A better service to customers and clients.

To the individual, the benefits are:

- Job security;

- Help with work related problems;

- $\quad$ Better pay;

- Job satisfaction;

- $\quad$ Prospect of advancement; and

- $\quad$ Opportunity of realizing potentials.

Ajileye (1992: 160) opines that training and development are seen as expression of management's desire to assist workers to attain the apogee of self fulfillment. Ndiomu (1992) quoting Appleby says training:

- $\quad$ Improves efficiency and morale;

- Introduction for succession enabling qualified replacement to be available;

- $\quad$ Raises standard of personnel;

- Develops supervisors and decreases the amount of supervision needed; and

- $\quad$ Leads to a reduction in scrap rate and improves machine utilization.

In addition, the findings of Collins (2008) on the effect of on-the-job training on Intercontinental bank workers revealed that training make workers to be confident, enriches employee's knowledge and increased performance skill, creates greater efficiency and effectiveness, increases productivity and leads to higher profitability. The study further revealed that there exist a direct relationship between manpower training and productivity of 
Bank workers. Training improves the productivity of employees and that of the organization and increases profitability arising from staff efficiency. The following are the effects of training on the organization namely;

- $\quad$ Quick and efficient service to customers;

- $\quad$ Eliminating waste through competitive job performance;

- $\quad$ Low labour turnover;

- $\quad$ Rapid expansion of the organization;

- Increase in the network of the organization human capital; and

- Gain government recognition as a responsible corporate citizen.

According to Nickels (2009) the effects of training on employee's performance encourage growth within the worker and the organization itself. Training can lead to self-fulfilling prophecy of enhanced output by employee, employee development equals decrease operational costs, leads to greater loyalty to the organization and as well enhanced job satisfaction. He further said that the effects of training on employee performance include meeting and exceeding expectations, cross training of staff, preparing employees for promotion, maintaining a safe environment and reduction of errors. The study carried out by Adekoya (2012) on the effects of training and retraining on the performance and productivity level of teachers in Edo State revealed that training helps to upgrade and develop teachers' skills, knowledge and competences for maximum performance and productivity, adjust to changes in the nature of their work, boost the morale of teachers and inculcate the right attitude towards their work.

In addition, the findings of the study carried out by Grips and Savermann (2010) revealed that training of agents had significant effects on the productivity of workers in the organization. In the same vein, Laplargne and Bensted (1999) are of the opinion that labour productivity growth appears to be enhanced by the joint introduction of training and innovation. This is due to the fact that training requires the support of innovation to benefit labour productivity growth. Zymelman (1976), Myers and Pigors (1981) have also listed a number of benefits to be gained by training employees. According to them, orientation and induction training programme for instance provide new employees the general information that they need about the organization's policies, procedures, practices and rules that will affect them and also about the jobs they are to perform as obtained in accurate and comprehensive job description. Training provided to workers helps the organization to function at an optimum level of productivity which is a direct effort of all employees. Training brings about change in behaviour with terminal objectives to achieve the goals of the organization through optimal use of manpower. In line with the above, Mitchell (1978) said training can be seen as an attempt by organization to change the behaviour of its members through learning process in order to increase efficiency and effectiveness.

Training and re-training help workers to become more confident in themselves and have a sense of belonging and commitment to the achievement of organizational goal. Hence, if workers receive necessary educational and developmental opportunities necessary to perform their work well, they will not only work with dedication but will aspire to achieve excellence on the job (Ajileye, 1992). Training and re-training of both old and new workers in an 
organization is not only aimed at promoting the ability of workers concerned but also promote the good image of the organization as well as preparing workers for taking up higher responsibilities when vacancy occurs. Amuno (1989) is of the opinion that, those organizations that invest resources in workers' training stand the chance of gaining a lot. Definitely, the organization stands a better chance of increased productivity in their various enterprises than those who do not invest in the development of their workers. It is also evident that organizations reap much more benefits than the workers themselves. Therefore, training serves as a motivating force in improving the efficiency and productivity of the workers in Nigeria.

\section{Problems/Challenges affecting the Training of Workers}

There are many challenges affecting workers' training in Nigeria which include:

1. Lack of constant training of workers is one of the problems affecting training of workers in the organization. Most organizations do not engage in constant training of their workers in order to upgrade their obsolete skills. They are of the opinion that money used for workers' training can be channel to other areas in the organization.

2. Inadequate Finance. Finance is one of the major challenges affecting workers' training in the organization. Budgetary allocation to training is too small to carry out any meaningful training on workers. As a result few workers benefit from training in most organization.

3. Most organization neglect on - the - job training for their workers. Workers are no longer trained on the job thereby making their skills on the job obsolete. This will greatly affect their efficiency at work since the world of work is constantly experiencing technological innovations.

\section{Conclusion}

The paper has attempted to discuss the meaning of worker, training and re-training, types of training to workers, objectives of training and equally the effects of training on workers' productivity in the organization. For any organization to maintain higher productivity, the organization must engage in training and re-training of its workforce to meet technological changes taking place in the world of work. This is to ensure improved performance on the job and boost the morale of workers in Nigeria.

\section{Recommendations}

The following recommendations are therefore made to improve workers' productivity in the organization.

1. Workers should constantly be trained and retrained to upgrade and update their obsolete skills and knowledge to meet the demand of their work.

2. Periodic training and retraining programmes such as seminars, conferences and workshops should be organized for workers to keep them abreast of innovations and technological changes in their work. 
3. Adequate financial allocation should be allocated to training and such should be released for the execution of training and development programmes for a particular year.

4. On - the- job training as the most popular of training should be encouraged by organizations as it remains the best and greater way of learning.

5. In - service training are not the only means of increasing productivity and therefore other adequate motivation should be given to the workers to ensure higher productivity.

\section{References}

Achive, B. (2008). Effect of training and manpower development on productivity of workers; retrieved from htpp://www.adekass.blogspot.com/impact-of-motivation-on-employee.html on October 6th, 2011

Adekoya, S. A. (2012). The effect of training and retraining on the performance and productivity level of teachers in secondary schools in Egor Local Government Area of Edo State, Unpublished project, University of Benin.

Ajileye, J.A. (1992). Staff welfare scheme: A strategy for motivation in A.D Yahaya and C.I. Akinyele (eds); New Trend in Personnel Management, ASCON, Badagry- Lagos. 160.

Akinwale, E.J. (2000). Human resources management: An overview in Nigeria: Tribune No. 12 (35): Tuesday - June.

Amuno, J.O.E. (1989). The effect of training on the job performance of graduates of the centre for Management Development in Nigeria. Unpublished PhD Thesis, University of Ibadan.

Beach, D.S. (1985). Personnel: The management of people at work; New York: Macmillan Publishing Company. $5^{\text {th }}$ Edition.

Collins, K. (2008). Effect of training and manpower development on productivity of workers; retrieved from htpp://www.adekass.blogspot.com/impact-of-motivation-on-employee.html on October 6th, 2011.

Dearden, L, Reed, R \& Reenen, J.V. (2005). The Impact of Training on Productivity and Wages: Evidence from British Panel Data. Retrieved on October 9th 2011 from http://ideas.respec.org/p/cep/dp067.html.

Egungwu, V. N. (1992). Human resources development and utilization in Nigerian private enterprises in A.D. Yahaya and C.I. Akinyele (eds.); Human Resources Development and Utilization : Policies and Issues; ASCON; Badagry, Lagos p 100.

Federal Republic of Nigeria (2004). National policy on education, Lagos, Federal Ministry of Education. 
Grip, A. D. \& Saverman, J. (2010). The effects of training on own and co-workers productivity: Evidence from a field experiment; retrieved from http://wharton.upenn.edu/awfe2010conferencepaper/savermann on October 6th 2011 http://wiki.answers.com/Qtraining\&development-meaning-definition-human-resourcemanagement.

Http://training and development:naukrichub.com

http://.your dictionary.com/workers. Retrieved on October 5th, 2011.

Imhabekhai, C. I. (2000). Manpower Training and retraining for effective healthcare delivery; Benin Journal of Education Studies, (12 \& 13) $1 \& 2$.

Imhabekhai, C. I. and Oyitso, M. O. (2000). Theory and practice of Industrial Relations; Benin, Monose Amalgamates

Jackson, V. S. \& Schuler, B. A. (2003). Meaning of Training and Development; retrieved on October 2nd, 2011 from http://www.writework.com/essay

Lane, S.T \& Robison, K. C. (1995). Meaning of training and development; retrieved on October 2nd, 2011 from http://www.writework.com/essay

Maduabum, C. (1992). Identification of training needs in A. D. Yahaya and C. I. Akinyele (eds.); New Trend in Personnel Management, ASCON, Badagry, Lagos, 183.

Nwachukwu, C.C. (1998). Management: Theory and Practice; Onitsha, Africana FEP Publishers Ltd.

Omole, M.A.L (1999). Industrial Education and Human Resources Development; Ibadan: Alafas Nigeria company.

Wikipedia (2011). Meaning of worker, retrieved on October 2nd, 2011 from http:/www.the free dictionary.com/worker.

Wikipedia (2011). Definition of training; retrieved on October 6th, 2011 from http://en.wikipedia.org/wiki/training 